\title{
De novo cholesterol synthesis in three different animal models of diabetes
}

\author{
K. R. Feingold, S. R. Lear and A. H. Moser \\ Department of Medicine, University of California, San Francisco and Metabolism Section, Medical Service, \\ Veterans Administration Medical Center, San Francisco, California, USA
}

\begin{abstract}
Summary. Recent studies have demonstrated that cholesterol synthesis is increased two- to threefold in the intestines of streptozotocin-induced diabetic rats. Cholesterol synthesis in tissues other than the intestines, including the liver, was not significantly altered by diabetes. In diabetic Chinese hamsters, cholesterol synthesis was increased 2.5 -fold in both the small and large intestine. These observations are similar to our findings in diabetic rats and suggest that a stimulation of intestinal cholesterogenesis may be a uniform phenomenon in insulinopenic diabetes. In $\mathrm{db} / \mathrm{db}$ mice, cholesterol synthesis was increased in both the liver and intestines but quantitatively the increase in hepatic cholesterogenesis was of much greater magnitude. Cholesterol feeding, which markedly inhibited hepatic cholesterol synthesis in both control and $\mathrm{db} / \mathrm{db}$ mice, did not obliterate this difference in hepatic cholesterol synthesis. In ob/ob mice, the severity of the metabolic disturbances
\end{abstract}

was less than that observed in $\mathrm{db} / \mathrm{db}$ mice and no abnormalities in cholesterol synthesis were observed in animals ingesting a low cholesterol diet. However, in ob/ob mice fed a high cholesterol diet, hepatic cholesterol synthesis was increased. These observations suggest that in obese insulin resistant diabetic animals of milder severity, the abnormality in hepatic cholesterol synthesis manifests itself only when the animals are ingesting a high cholesterol diet. The results of this and previous studies suggest that in insulinopenic diabetes there is a stimulation of cholesterol synthesis that is localized to the intestines, whereas in obese, insulin-resistant diabetic animals, cholesterol synthesis is altered in the liver.

Key words: Cholesterol synthesis, diabetic Chinese hamsters, $\mathrm{ob} / \mathrm{ob}$ mice, $\mathrm{db} / \mathrm{db}$ mice, tritiated water, sterol synthesis.
Recent studies using tritiated water as the radiolabel for quantifying cholesterogenesis demonstrated that in intact animals cholesterol synthesis is increased two- to threefold in the gut of streptozotocin-induced diabetic rats compared with controls [1]. Enhancement of cholesterogenesis occurred soon after the onset of diabetes and persisted for an extended period of time. The increase in gut cholesterol synthesis was due to the stimulation of cholesterogenesis in both the small and large intestine of the diabetic rat, but quantitatively, the small intestine was primarily responsible for the observed increase in cholesterogenesis. Studies of the incorporation of acetate into cholesterol in vitro have also demonstrated increased cholesterol synthesis in the small intestine of the diabetic rat [2]. In addition, diabetes has been shown to increase the activity of 3-hydroxy-3methylglutaryl coenzyme A reductase, the rate limiting enzyme of cholesterol synthesis, in the rat small intestine [2-4]. Cholesterol feeding, which did not affect cholesterol synthesis in either the small or large intestines of normal animals, resulted in a marked reduction in small intestinal cholesterol synthesis in diabetic rats to levels that were similar to those observed in controls [5]. In contrast, cholesterol ingestion did not affect the increased cholesterol synthesis observed in the large intestines of diabetic animals [5]. Cholesterol synthesis in tissues other than the intestines, such as the liver, skin, stomach and remaining carcass, was not significantly altered by diabetes [1]. Most importantly, insulin therapy, which normalized blood glucose, markedly decreased gut cholesterol synthesis to levels only slightly greater than those in controls [1].

Cholesterol synthesized by the intestines has two major fates. Firstly, these sterols can be utilized in situ by intestinal cells for the synthesis and maintenance of cell membranes. Secondly, the newly synthesized sterols can be transported by the lymph to the bloodstream and it is well known that the intestines are an important source of plasma cholesterol $[6,7]$. Studies in control and streptozotocin-induced diabetic rats whose thoracic ducts were cannulated have demonstrated that newly synthesized cholesterol in the 24-h lymph drainage was 
increased in the diabetic animals compared with controls [8]. These observations suggest that the increased cholesterol synthesized in the intestines of diabetic animals potentially contributes to the elevation of plasma cholesterol that is characteristic of diabetes.

The purpose of the present study was to determine whether other animal models of diabetes demonstrated similar disturbances in cholesterol synthesis as were noted in the streptozotocin-induced diabetic rat. The three models that we chose to study were the $\mathrm{db} / \mathrm{db}$ mouse, the ob/ob mouse, and the diabetic Chinese hamster. Both the $\mathrm{db} / \mathrm{db}$ and ob/ob mouse develop a genetic type of diabetes that is associated with obesity, hyperinsulinaemia and insulin resistance [9]. These animal models are thus analogous to non-insulin-dependent diabetes. The spontaneously diabetic Chinese hamsters used in the present study are thin, insulinopenic and mildly ketotic and, thus, are analogous to an insulin-dependent diabetic model [10]. It should be noted that the streptozotocin-induced diabetic rat also represents an insulinopenic, insulin-dependent animal model of diabetes.

\section{Methods}

\section{Animals}

The diabetic Chinese hamsters and control animals wete kindly provided by Dr. G.C.Gerritsen, Upjohn, Kalamazoo, Michigan. The ob/ $\mathrm{ob}$ and control mice $+/+($ Strain $\mathrm{C} 57 \mathrm{BL} / 6 \mathrm{~J})$ and $\mathrm{db} / \mathrm{db}$ and control mice $+/+$ or $+/ \mathrm{db}$ (Strain C57BL/KsJ) were purchased from Jackson Laboratories, Bar Harbor, Maine. Animals were maintained on a reverse 12-h light cycle (03,00-15.00 h dark, $15.00-03.00 \mathrm{~h}$ light) for a minimum of 2 weeks. The mice were fed rat and mouse diet (Simonsen, Gilroy, California) and water ad libitum. Where indicated, a $2 \%$ cholesterol diet (ICN Biochemicals, Cleveland, Ohio) was substituted for the usual chow. The Chinese hamsters were fed Purina Mouse Breeder Chow (St. Louis, Missouri) and water ad libitum.

\section{Materials}

Tritiated water $(1 \mathrm{Ci} / \mathrm{g})$ and $26-{ }^{14} \mathrm{C}$-cholesterol $(0.5 \mathrm{Ci} / 0.33 \mathrm{~g})$ were purchased from New England Nuclear, Boston, Massachusetts. Before use, the purity of the ${ }^{14} \mathrm{C}$-cholesterol was determined by thin layer chromatography and found to be $>95 \%$ pure. Thin layer polygram sil $\mathrm{G}$ plates were purchased from Brinkmann Instruments, Westbury, New York. Ultrafluor scintillation fluid was obtained from National Diagnostics, Somerville, New Jersey. Ketodiastix were obtained from Ames, Elkhart, Indiana.

\section{Experimental protocol}

Between 08.00 and $09.00 \mathrm{~h}$ the aminals were injected IP with ${ }^{3} \mathrm{H}_{2} \mathrm{O}$ $(10 \mathrm{mCi})$. The animals did not have access to either food or water during these experiments. Six hours later the animals were killed, weighed and a blood specimen obtained. In two experiments, the animals were injected with $20 \mathrm{mCi}$ of ${ }^{3} \mathrm{H}_{2} \mathrm{O}$ and killed $1 \mathrm{~h}$ later. The serum was separated by centrifugation. The organs studied were removed and individually weighed and saponified by refluxing overnight in a solution of $45 \%$ potassium hydroxide, water, and $70 \%$ ethyl alcohol (2:1:5). After cooling an internal standard of ${ }^{14} \mathrm{C}$-cholesterol was added before extracting the cholesterol three times with petroleum ether $(25 \mathrm{ml})$. In some instances, the petroleum ether extract was washed with $50 \%$ ethanol- $\mathrm{H}_{2} \mathrm{O}(15 \mathrm{ml})$, dried, dissolved in chloroform and applied to thin layer chromatography plates. The plates were developed in ethyl acetate: benzene $(1: 5)$ for $50 \mathrm{~min}$ and the band corresponding to standards of cholesterol was cut from the plate and counted. The gain and discriminator window settings of the scintillation counter (Beckman Instruments, Irvine, California) were adjusted so that $<0.2 \%$ of the ${ }^{3} \mathrm{H}$ counts were recorded in the ${ }^{14} \mathrm{C}$ window and approximately $10 \%$ of the ${ }^{14} \mathrm{C}$ counts were recorded in the ${ }^{3} \mathrm{H}$ window. Calculations were corrected for the spillover of ${ }^{3} \mathrm{H}$ and ${ }^{14} \mathrm{C}$, for background, and for recovery of internal standard. The spec. act. of ${ }^{3} \mathrm{H}$ was determined for each animal by measuring the $\mathrm{dpm} / \mathrm{ml}$ of plasma at the end of the experiment and dividing by mol water/ $\mathrm{ml}$ plasma ( $52 \mathrm{mmol} / \mathrm{ml}$ plasma, assuming that plasma is $92 \%$ water). In each individual experiment, the spec. act. was similar in the control and diabetic animals.

Digitonin precipitable sterols were determined after saponification and petroleum ether extraction. The dried petroleum ether extract was solubilized in acetone: ethanol (1:1). The acetone: ethanol was neutralized with $10 \%$ acetic acid and then incubated with $0.5 \%$ digitonin in $50 \%$ ethanol overnight $(12 \mathrm{~h})$ at room temperature. The digitonin precipitable sterols were centrifuged at $2,500 \mathrm{rev} / \mathrm{min}$ for $15 \mathrm{~min}$ and the supernatant discarded. The precipitate was then washed with acetone : diethyl ether $(1: 2)$, centrifuged and dried. This wash procedure was repeated twice more with anhydrous diethyl ether. The digitonin precipitate was dissolved in pyridine, water added and the mixture extracted with petroleum ether. The dried petroleum ether extract was counted in Ultrafluor under the conditions described above.

Tissue cholesterol content was assayed by the method of Ham using the dried petroleum ether extract of saponified tissue [11]. Two $\mathrm{ml}$ of a solution of paratoluene sulphonic acid $(80 \mathrm{~g})$ made up to 1 litre with glacial acetic acid and $100 \mathrm{ml} \mathrm{H}_{2} \mathrm{SO}_{4}$ was added to each extract and after incubation in a boiling water bath for $5 \mathrm{~min}$ and cooling, the absorption determined at $475 \mathrm{~nm}$ with a spectrophotometer (Beckman Model 24, Beckman Instruments, Irvine, California). Serum glucose was measured with a glucose analyzer (Yellow Springs Instruments, Yellow Springs, Ohio). Statistical significance was determined using a two tailed Student's t-test.

\section{Results}

\section{Cholesterol synthesis in diabetic Chinese hamsters}

In the diabetic Chinese hamster cholesterol synthesis was significantly increased in both the small and large intestine (Table 1). In the small intestine, cholesterol synthesis was increased 2.5 -fold $(p<0.001)$ and in the large intestine 2.4 -fold $(p<0.001)$ compared with controls. This difference in cholesterogenesis persists in both the small and large intestine, even when the data are expressed on a per $g$ weight basis. Hepatic cholesterol synthesis on either a total organ or a per $\mathrm{g}$ weight basis was not significantly different in the diabetic Chinese hamsters. These results indicate that, similar to observations in streptozotocin-induced diabetic rats, cholesterol synthesis in both the small and large intestine is enhanced in diabetic Chinese hamsters.

\section{Cholesterol synthesis in $d b / d b$ mice}

Cholesterol synthesis was compared in control and $\mathrm{db} /$ $\mathrm{db}$ mice at 6,9, and 12 weeks of age (Table 2). As expected, at the three age groups studied, the total body 
Table 1. Cholesterol synthesis in control and diabetic Chinese hamsters

\begin{tabular}{|c|c|c|c|c|c|c|c|c|}
\hline \multirow[t]{3}{*}{ Hamsters } & \multicolumn{4}{|l|}{ Weight (g) } & \multirow[t]{3}{*}{ Glucose $(\mathrm{mmol} / \mathrm{l})$} & \multirow{2}{*}{\multicolumn{3}{|c|}{$\begin{array}{l}{ }^{3} \mathrm{H}_{2} \mathrm{O} \text { incorporated into cholesterol } \\
\left(\mu \mathrm{mol} \cdot \text { organ }^{-1} \cdot 6 \mathrm{~h}^{-1}\right)\end{array}$}} \\
\hline & \multirow[t]{2}{*}{ Total body } & \multirow[t]{2}{*}{ Liver } & \multirow{2}{*}{$\begin{array}{l}\text { Small } \\
\text { intestine }\end{array}$} & \multirow{2}{*}{$\begin{array}{l}\text { Large } \\
\text { intestine }\end{array}$} & & & & \\
\hline & & & & & & Liver & $\begin{array}{l}\text { Small } \\
\text { intestine }\end{array}$ & $\begin{array}{l}\text { Large } \\
\text { intestine }\end{array}$ \\
\hline Control $(n=9)$ & $24.7 \pm 0.8$ & $1.19 \pm 0.4$ & $0.90 \pm 0.05$ & $1.12 \pm 0.06$ & $\begin{array}{c}7.0 \pm 0.3 \\
(6.0 \pm 0.2)\end{array}$ & $1.73 \pm 0.35$ & $1.10 \pm 0.09$ & $1.10 \pm 0.11$ \\
\hline \multirow[t]{2}{*}{ Diabetic $(n=7)$} & $25.3 \pm 1.3$ & $1.51 \pm 0.07$ & $1.40 \pm 0.05$ & $1.95 \pm 0.15$ & $\begin{array}{c}18.1 \pm 0.8 \\
(19.4 \pm 0.9)\end{array}$ & $3.36 \pm 0.81$ & $2.76 \pm 0.32$ & $2.63 \pm 0.19$ \\
\hline & NS & $p<0.01$ & $p<0.001$ & $p<0.001$ & $\begin{array}{c}p<0.001 \\
(p<0.001)\end{array}$ & NS & $p<0.001$ & $p<0.001$ \\
\hline
\end{tabular}

Results are expressed as mean \pm SEM. Serum glucose values were obtained at the termination of study; values in parentheses are fasting levels obtained several weeks before the study. NS = not significant.

Table 2. Cholesterol synthesis in control, $\mathrm{db} / \mathrm{db}$ and $\mathrm{ob} / \mathrm{ob}$ mice

\begin{tabular}{|c|c|c|c|c|c|c|}
\hline \multirow[t]{3}{*}{ Mice } & \multicolumn{3}{|l|}{ Weight (g) } & \multirow{2}{*}{\multicolumn{2}{|c|}{$\begin{array}{l}{ }^{3} \mathrm{H}_{2} \mathrm{O} \text { incorporated into cholesterol } \\
\left(\mu \mathrm{mol} \cdot \mathrm{organ}^{-1} \cdot 6 \mathrm{~h}^{-1}\right)\end{array}$}} & \multirow{3}{*}{$\begin{array}{l}\text { Serum glucose } \\
\text { concentration } \\
(\mathrm{mmol} / \mathrm{l})\end{array}$} \\
\hline & \multirow{2}{*}{ Total body } & \multirow{2}{*}{ Liver } & \multirow{2}{*}{ Gut } & & & \\
\hline & & & & Liver & Gut & \\
\hline $\mathrm{db} / \mathrm{db}(n=4)$ & $31.0 \pm 0.6^{\mathrm{a}}$ & $2.23 \pm 0.17^{\mathrm{a}}$ & $2.17 \pm 0.14^{b}$ & $11.3 \pm 0.6^{\mathrm{c}}$ & $6.9 \pm 0.5^{\mathrm{b}}$ & $29.1 \pm 3.0^{\mathrm{a}}(n=8)$ \\
\hline Control $(n=4)$ & $17.9 \pm 0.95$ & $0.98 \pm 0.02$ & $1.65 \pm 0.01$ & $6.2 \pm 0.7$ & $5.1 \pm 0.2$ & $8.2 \pm 0.9(n=8)$ \\
\hline $\mathrm{ob} / \mathrm{ob}(n=4)$ & $37.2 \pm 1.5^{\mathrm{a}}$ & $3.06 \pm 0.18^{\mathrm{a}}$ & $2.18 \pm 0.08^{c}$ & $8.6 \pm 0.6$ & $3.9 \pm 0.2$ & $11.6 \pm 0.8^{\mathrm{a}}(n=16)$ \\
\hline \multicolumn{7}{|l|}{9 weeks } \\
\hline $\mathrm{db} / \mathrm{db}(n=5)$ & $36.1 \pm 1.5^{a}$ & $2.47 \pm 0.18^{\mathrm{a}}$ & $2.70 \pm 0.11^{\mathrm{a}}$ & $13.4 \pm 2.1^{\mathrm{c}}$ & $6.9 \pm 0.6^{\mathrm{d}}$ & $17.8 \pm 2.2^{\mathrm{a}}(n=8)$ \\
\hline Control $(n=5)$ & $17.6 \pm 0.2$ & $0.89 \pm 0.02$ & $1.33 \pm 0.01$ & $6.1 \pm 0.3$ & $5.0 \pm 0.3$ & $6.1 \pm 0.6(n=7)$ \\
\hline $\mathrm{ob} / \mathrm{ob}(n=4)$ & $40.8 \pm 0.9^{\mathrm{a}}$ & $2.83 \pm 0.15^{\mathrm{a}}$ & $2.05 \pm 0.09^{c}$ & $12.4 \pm 0.4$ & $6.7 \pm 0.3$ & $12.3 \pm 0.7^{d}(n=4)$ \\
\hline Control $(n=4)$ & $19.1 \pm 0.4$ & $0.96 \pm 0.06$ & $1.43 \pm 0.08$ & $10.9 \pm 1.2$ & $6.8 \pm 0.6$ & $7.9 \pm 0.6(n=4)$ \\
\hline \multicolumn{7}{|l|}{12 weeks } \\
\hline
\end{tabular}

The results are expressed as mean \pm SEM with the number of mice in parentheses.

${ }^{\mathrm{a}} p<0.001 ;{ }^{\mathrm{b}} p<0.02 ;{ }^{\mathrm{c}} p<0.1 ;{ }^{\mathrm{d}} p<0.05$

weight, liver weight, and gut weight were increased in the $\mathrm{db} / \mathrm{db}$ mice compared with control mice. The $\mathrm{db} /$ $\mathrm{db}$ mice also, as expected, exhibited marked hyperglycaemia with blood glucose concentrations at 6 and 12 weeks averaging approximately $28.5 \mathrm{mmol} / 1$ (Table 2). Hepatic cholesterol synthesis was significantly increased at 6,9 , and 12 weeks of age in the $\mathrm{db} / \mathrm{db}$ mice. This enhancement of cholesterol synthesis in the livers of $\mathrm{db} / \mathrm{db}$ mice compared with controls varied from as high as a 2.2-fold increase at 9 weeks $(p<0.01)$ to as low as a 1.5 -fold increase at 12 weeks $(p<0.01)$. It should be noted that hepatic cholesterol synthesis was also increased 2.1-fold $1 \mathrm{~h}$ after the administration of ${ }^{3} \mathrm{H}_{2} \mathrm{O}$ in 9 week old $\mathrm{db} / \mathrm{db}$ mice, demonstrating that the inter-organ transfer of cholesterol during the above studies did not account for our observations (control: $1.34 \pm 0.20$ versus $\mathrm{db} / \mathrm{db}$ mice: $2.81 \pm 0.31$ umol ${ }^{3} \mathrm{H}_{2} \mathrm{O}$ incorporated $\left.\cdot \operatorname{organ}^{-1} \cdot \mathrm{h}^{-1}, p<0.01\right)$. Clearly, because of the marked hypertrophy of livers of $\mathrm{db} / \mathrm{db}$ mice, if the results were presented on a per $g$ weight basis, cho- lesterol synthesis would be decreased in the livers of the $\mathrm{db} / \mathrm{db}$ mice in comparison to controls. It must be recognized, though, that a significant portion of the increase in liver weight in the $\mathrm{db} / \mathrm{db}$ animals is secondary to fatty infiltration. Moreover, from the point of view of cholesterol balance of the organism, cholesterol synthesis expressed per total organ is probably of greater significance than that expressed per unit of mass.

Cholesterol synthesis was significantly increased also in the gut (small intestine and large intestine) of $\mathrm{db} / \mathrm{db}$ mice at 6 and 9 weeks. At 12 weeks the increase in cholesterol synthesis in the gut of $\mathrm{db} / \mathrm{db}$ mice was not statistically significant. It should be noted that, quantitatively, in comparison to the large difference in cholesterol synthesis in the livers, the difference in cholesterol synthesis between the gut of control and $\mathrm{db} / \mathrm{db}$ mice is small. Figure 1 illustrates the distribution of cholesterol synthesis in the gut of control and $\mathrm{db} / \mathrm{db}$ mice. Cholesterol synthesis was significantly increased in the small intestine of $\mathrm{db} / \mathrm{db}$ animals (control: 3.8 versus 
Table 3. Effect of cholesterol feeding on cholesterol synthesis in control, $\mathrm{db} / \mathrm{db}$, and $\mathrm{ob} / \mathrm{ob}$ mice

\begin{tabular}{|c|c|c|c|c|c|}
\hline \multirow[t]{3}{*}{ Mice } & \multicolumn{3}{|l|}{ Weight (g) } & \multirow{2}{*}{\multicolumn{2}{|c|}{$\begin{array}{l}{ }^{3} \mathrm{H}_{2} \mathrm{O} \text { incorporated into cholesterol } \\
\left(\mu \mathrm{mol} \cdot \text { organ }^{-1} \cdot 6 \mathrm{~h}^{-1}\right)\end{array}$}} \\
\hline & \multirow{2}{*}{ Total body } & \multirow{2}{*}{ Liver } & \multirow{2}{*}{ Gut } & & \\
\hline & & & & Liver & Gut \\
\hline \multicolumn{6}{|l|}{6 weeks } \\
\hline $\mathrm{db} / \mathrm{db}(n=4)$ & $31.6 \pm 1.9$ & $2.54 \pm 0.23$ & $2.54 \pm 0.17$ & $2.4 \pm 0.4$ & $3.3 \pm 0.1$ \\
\hline \multirow[t]{2}{*}{ Control $(n=4)$} & $18.1 \pm 0.6$ & $0.98 \pm 0.03$ & $1.76 \pm 0.05$ & $0.5 \pm 0.1$ & $3.0 \pm 0.2$ \\
\hline & $p<0.001$ & $p<0.001$ & $p<0.01$ & $p<0.01$ & NS \\
\hline Control $(n=4)$ & $p<0.001$ & $p<0.001$ & $p<0.001$ & $p<0.001$ & NS \\
\hline \multicolumn{6}{|l|}{12 weeks } \\
\hline $\mathrm{db} / \mathrm{db}(n=3)$ & $52.5 \pm 1.3$ & $5.79 \pm 0.49$ & $2.89 \pm 0.03$ & $1.2 \pm 0.2$ & $2.2 \pm 0.2$ \\
\hline \multirow[t]{2}{*}{ Control $(n=4)$} & $20.9 \pm 1.0$ & $1.27 \pm 0.04$ & $1.89 \pm 0.14$ & $0.5 \pm 0.1$ & $2.0 \pm 0.1$ \\
\hline & $p<0.001$ & $p<0.001$ & $p<0.01$ & $p<0.05$ & NS \\
\hline $\mathrm{ob} / \mathrm{ob}(n=4)$ & $45.1 \pm 1.8$ & $3.15 \pm 0.25$ & $2.69 \pm 0.15$ & $3.22 \pm 0.28$ & $3.2 \pm 0.3$ \\
\hline
\end{tabular}

The results are expressed as mean \pm SEM

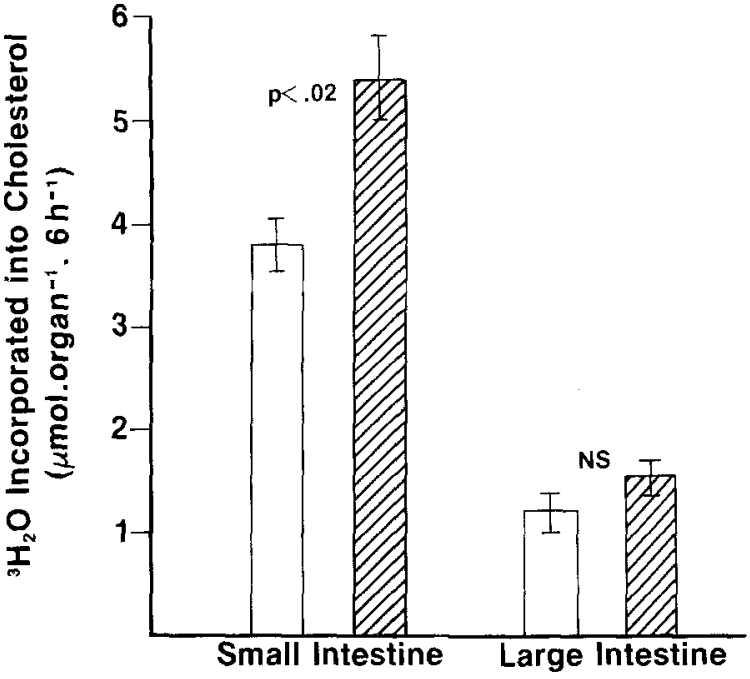

Fig. 1. Control and $\mathrm{db} / \mathrm{db}$ mice were fed a low cholesterol diet ad libitum. At 9 weeks of age, animals were injected IP with $10 \mathrm{mCi}$ of ${ }^{3} \mathrm{H}_{2} \mathrm{O}$. At $6 \mathrm{~h}$ the animals were killed and the small and large intestines were saponified and ${ }^{3} \mathrm{H}$-cholesterol was assayed. Data presented are mean \pm SEM. $\square$ control $n=5 ; \square \mathrm{db} / \mathrm{db}$ mice, $n=5$

$\mathrm{db} / \mathrm{db}$ mice: $5.4 \mu \mathrm{mol}{ }^{3} \mathrm{H}_{2} \mathrm{O}$ incorporated into cholesterol in $6 \mathrm{~h}, p<0.02)$ but was similar in the large intestine.

These results demonstrate that, in contrast to our observations of the major importance of intestinal cholesterogenesis in streptozotocin-induced diabetic rats and diabetic Chinese hamsters, in $\mathrm{db} / \mathrm{db}$ mice, cholesterol synthesis was enhanced primarily in the liver, with only a modest and variable increase in the intestine.

\section{Cholesterol synthesis in $o b / o b$ mice}

Cholesterol synthesis was compared in control and ob/ ob mice at 6, 9, and 12 weeks of age (Table 2). Total body weight, liver weight, and gut weight were signifi-

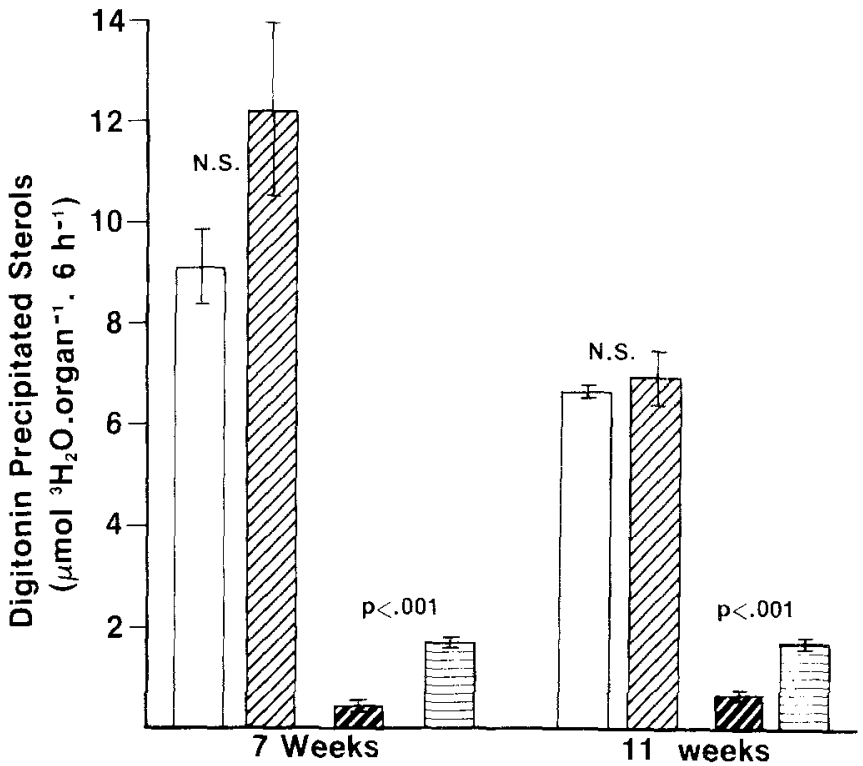

Fig. 2. Control and ob/ob mice were fed either a low cholesterol diet or a $2 \%$ cholesterol diet. At 7 and 11 weeks of age, animals were injected IP with $10 \mathrm{mCi}$ of ${ }^{3} \mathrm{H}_{2} \mathrm{O}$. At $6 \mathrm{~h}$ the animals were killed and the liver saponified and assayed for ${ }^{3} \mathrm{H}$-cholesterol after extraction with petroleum ether and digitonin precipitation as described in the Methods section. Data presented are mean \pm SEM. There were four animals in each group: $\square$; control; $\square$ ob/ob mice; control, cholesterol-fed mice; $\mathrm{ob} / \mathrm{ob}$, cholesterol-fed mice

cantly increased at all ages in the ob/ob mice compared with control mice. As expected, the ob/ob mice were also hyperglycaemic but, in comparison to the $\mathrm{db} / \mathrm{db}$ mice, the degree of hyperglycaemia was relatively modest in the ob/ob animals (Table 2). Cholesterol synthesis at all age periods studied was similar in the liver and gut of the control and ob/ob mice. There was also no difference in cholesterol synthesis in either the small or large intestine of control and ob/ob mice. These findings demonstrate that hyperglycaemia, to the degree observed in genetically diabetic ob/ob mice (C57BL/6J 
strain), does not stimulate cholesterol synthesis in either the intestines or liver.

\section{The effect of cholesterol feeding on cholesterol synthesis in $\mathrm{db}, \mathrm{db}$ mice}

Hepatic cholesterol synthesis is enhanced in cholesterol-fed $\mathrm{db} / \mathrm{db}$ mice (Table 3). At 6 weeks, cholesterol synthesis was increased 4.8 -fold $(p<0.01)$ and at 12 weeks 2.4-fold $(p<0.05)$ in the liver of cholesterolfed $\mathrm{db} / \mathrm{db}$ mice compared with control mice. In comparison to mice studied simultaneously, ingesting the usual low cholesterol diet, hepatic cholesterol synthesis was markedly inhibited in both control and $\mathrm{db} / \mathrm{db}$ mice (cholesterol-fed control 8\%, 9\%; cholesterol-fed db/db mice $21 \%, 14 \%)$. Cholesterol synthesis in the gut of cholesterol-fed control and $\mathrm{db} / \mathrm{db}$ mice was not significantly different. These results indicate that cholesterol feeding, while significantly inhibiting hepatic cholesterol synthesis in both groups of animals, does not obliterate the previously observed increase in cholesterol synthesis in the livers of $d b / d b$ mice.

\section{The effect of cholesterol feeding on cholesterol synthesis in $o b / o b$ mice}

In the previous experiments, animals fed the usual low cholesterol diet failed to demonstrate a difference in cholesterol synthesis in the liver or gut of ob/ob and control animals. However, in mice ingesting a $2 \%$ cholesterol diet, cholesterol synthesis was relatively greater in the livers of the ob/ob mice (Table 3). Cholesterol synthesis was 4.6 -fold greater at 6 weeks $(p<0.001)$ and 7.2 -fold greater at 12 weeks $(p<0.001)$ in the ob/ob animals in comparison to controls. Similarly, $1 \mathrm{~h}$ after the administration of ${ }^{3} \mathrm{H}_{2} \mathrm{O}$ water, hepatic cholesterol synthesis was increased 5.5-fold in 11-week-old ob/ob mice compared to control mice. Cholesterol synthesis in the gut of the cholesterol-fed control and ob/ob mice was not significantly different.

To ascertain the validity of our observations, we repeated these studies using a different method, digitonin precipitation, for quantitating the incorporation of ${ }^{3} \mathrm{H}_{2} \mathrm{O}$ into cholesterol. Hepatic cholesterol synthesis at both 7 and 11 weeks in animals ingesting the usual low cholesterol diet was not significantly different in control and $\mathrm{ob} / \mathrm{ob}$ animals (Fig. 2 ). In animals fed a $2 \%$ cholesterol diet, cholesterol synthesis in the livers of both control and $\mathrm{ob} / \mathrm{ob}$ animals was markedly inhibited. However, cholesterogenesis in the cholesterol-fed ob/ob mice was significantly increased in comparison to controls, confirming our previous observations. Cholesterol synthesis was 3.9 -fold greater at 7 weeks $(p<0.001)$ and 2.6-fold greater at 11 weeks $(p<0.001)$ in the ob/ob animals. These results indicate that cholesterol synthesis in the liver of ob/ob mice was significantly increased compared with controls if the animals were ingesting a high cholesterol diet. This finding is in contradiction to the absence of a difference in hepatic synthesis in ob/ob and control mice fed a low cholesterol diet.

This difference in hepatic cholesterogenesis in cholesterol-fed animals was not likely to be secondary to a failure of gastrointestinal absorption or transport of cholesterol to the liver because, with cholesterol feeding, the total concentration of cholesterol increases significantly in the livers of both the control and ob/ob animals (control, $n=4: 4.43 \pm 0.08 \mathrm{mg} / \mathrm{g}$ liver, control cholesterol-fed, $n=4: 7.79 \pm 0.56 \mathrm{mg} / \mathrm{g}$ liver, ob/ob, $n=4: 5.29 \pm 1.08 \mathrm{mg} / \mathrm{g}$ liver, ob/ob cholesterol-fed, $n=4: 15.24 \pm 0.72 \mathrm{mg} / \mathrm{g}$ liver: control versus control cholesterol-fed $p<0.01, \mathrm{ob} / \mathrm{ob}$ versus ob/ob cholesterol-fed, $p<0.001$ ).

\section{Discussion}

In the present studies, cholesterol synthesis was quantified using tritiated water as the radiolabel in three different diabetic animal models. The diabetic Chinese hamsters are thin, insulinopenic, and mildly ketotic and thus represents an animal model of insulin-dependent diabetes [10]. The $\mathrm{db} / \mathrm{db}$ and ob/ob mice were obese, hyperinsulinaemic, and insulin-resistant and thus represent an animal model of non-insulin-dependent diabetes [9]. It should be recognized that as reported by others and observed in this study, the diabetes associated metabolic disturbances in the $\mathrm{db} / \mathrm{db}$ mouse (strain $\mathrm{C} 57 \mathrm{BL} / \mathrm{KsJ}$ ) was of much greater severity than that in the ob/ob mouse (strain C57BL/6J) [9].

In the diabetic Chinese hamsters, cholesterol synthesis was increased approximately 2.5 -fold in both the small and large intestine compared with control animals. In the liver, however, there was no significant difference in cholesterogenesis between control and diabetic Chinese hamsters. These observations are identical to our previous findings in streptozotocin-induced diabetic rats [1], another animal model of insulin-dependent diabetes, and suggest that a stimulation of intestinal cholesterogenesis may be a uniform phenomenon in poorly controlled insulin-dependent diabetes.

In the $\mathrm{db} / \mathrm{db}$ mouse, cholesterol synthesis was increased in both the liver and intestine but quantitatively the increase in hepatic cholesterogenesis in $\mathrm{db} / \mathrm{db}$ mice was of much greater magnitude. The increase in cholesterol synthesis in the liver of $\mathrm{db} / \mathrm{db}$ mice ranged from a 1.5 -fold at 12 weeks to 2.2 -fold at 9 weeks of age. Cholesterol feeding, which markedly inhibited hepatic cholesterol synthesis in both control and $\mathrm{db} / \mathrm{db}$ mice, did not obliterate the difference in hepatic cholesterol synthesis. Cholesterol synthesis in the liver of cholesterolfed $\mathrm{db} / \mathrm{db}$ mice was 4.08 -fold greater at 6 weeks and 2.4-fold greater at 12 weeks compared with cholesterolfed control animals. The small increase in intestinal cholesterol synthesis observed in $\mathrm{db} / \mathrm{db}$ mice ingesting the usual low cholesterol diet was not observed in the cholesterol feeding experiments. These observations 
suggest that, in contrast to insulin-dependent diabetes in which disturbances in intestinal cholesterol synthesis are of major importance, in severe non-insulin-dependent diabetes, increases in hepatic cholesterol synthesis are the primary abnormality associated with the diabetic state.

In the ob/ob mice fed the usual diet, no abnormalities in cholesterol synthesis were observed in either the liver or intestines. Earlier studies by Jansen et al employing ${ }^{14} \mathrm{C}$ glucose as the radiolabel and studies by Christophe and Mayer using ${ }^{14} \mathrm{C}$ acetate as the radiolabel also failed to demonstrate alterations in hepatic cholesterol synthesis in ob/ob mice [12, 13]. The basis for the differences in hepatic cholesterol synthesis in $\mathrm{ob} / \mathrm{ob}$ and $\mathrm{db} / \mathrm{db}$ mice is not known but one could speculate that it is perhaps related to differences in the severity of the metabolic disturbances in the two animal models of non-insulin-dependent diabetes.

In contrast to our observations in ob/ob mice fed the standard diet, experiments quantitating cholesterol synthesis in control and ob/ob animals fed a $2 \%$ cholesterol diet demonstrated differences in cholesterogenesis. In animals ingesting a $2 \%$ cholesterol diet, hepatic cholesterol synthesis was consistently increased ( 6 weeks, 4.6-fold; 7 weeks, 3.9-fold; 11 weeks, 2.6-fold; 12 weeks, 7.2 -fold) in ob/ob mice compared with control. No differences in intestinal cholesterol synthesis were observed. This difference was not due to a failure of exogenous cholesterol to be absorbed or transported to the liver because the hepatic cholesterol concentration increased significantly in both control and ob/ob mice. In fact, the magnitude of change in cholesterol concentration and the absolute final cholesterol concentration in the liver were greater in the cholesterol-fed $\mathrm{ob} / \mathrm{ob}$ animals than in cholesterol-fed controls. These observations indicate that there is an increase in hepatic cholesterol synthesis in ob/ob animals but that this abnormality manifests itself only when the animal is ingesting a high cholesterol diet. Thus, this animal model of non-insulin-dependent diabetes also exhibits a disturbance in hepatic cholesterogenesis.

In conclusion, the results of this and previous studies suggest that in poorly controlled insulin-dependent diabetes there is a stimulation in cholesterol synthesis which is localized to the intestines, whereas in non-insulin-dependent diabetes cholesterol synthesis is altered in the liver.

Acknowledgements. We acknowledge the excellent assistance of S. Shaddick. We would like to thank Dr. G.C.Gerritsen for so kindly providing us with control and diabetic Chinese hamsters. Most importantly, we acknowledge Dr. M.D.Siperstein, without whose help and support these studies would not have been possible. This work was supported by National Institutes of Health grants AM-32685 and CA-15979, the Upjohn Corporation, Medical Research Service of the Veterans Administration and by a grant from the American Heart Association, California Chapter. Dr. Feingold is the recipient of a National Institutes of Health Special Emphasis Research Career Award. The results of the studies on diabetic Chinese hamsters were presented at the International Diabetes Federation Meeting, Nairobi, Kenya, November 1982, and at Lessons from Animal Diabetes, Israel, November 1982

\section{References}

1. Feingold KR, Wiley MH, MacRae G, Moser AH, Lear SR, Siperstein MD (1982) The effect of diabetes mellitus on sterol synthesis in the diabetic rat. Diabetes $31: 388-395$

2. Nakayama H, Nakagawa S (1977) Influence of streptozotocin diabetes on intestinal 3-hydroxy-3-methylglutaryl coenzyme A reductase activity in the rat. Diabetes 26: 439-444

3. Young NL, Saudek CD, Crawford SA (1982) Total hydroxymethylglutaryl CoA reductase activity in the small intestine and liver of insulin-deficient rats. J Lipid Res $23: 266-275$

4. Goodman MW, Michels LD, Keane WF (1982) Intestinal and hepatic cholesterol synthesis in the alloxan diabetic rat. Proc Soc Exp Biol Med 170: 286-290

5. Feingold KR, Wiley MH, Moser AH, Lear SR (1983) The effect of cholesterol feeding and alterations in bile acid homeostasis on de novo sterologenesis in diabetic rats. Diabetes $32: 368-376$

6. Lindsey CA Jr, Wilson JD (1965) Evidence for a contribution by the intestinal wall to the serum cholesterol of the rat. J Lipid Res 6: 173-181

7. Wilson JD (1968) Biosynthetic origin of serum cholesterol in the squirrel monkey: evidence for a contribution by the intestinal wall. J Clin Invest 47: 175-187

8. Feingold KR, Wiley MH, Zsigmond G, Moser AH, Lear SR, Siperstein MD (1984). The importance of intestinal cholesterol synthesis in diabetic animals. In: E. Shafrir (ed) Lessons from animai diabetes. Elsevier, Amsterdam (in press)

9. Coleman DL (1982) Diabetes-obesity syndromes in mice. Diabetes 31 (Suppl 1): 1-6

10. Gerritsen GC (1982) The Chinese hamster as model for the study of diabetes mellitus. Diabetes 31 (Suppl 1): 14-23

11. Ham AB (1971) A new reagent for the determination of true cholesterol. Am J Med Technol 37: 319-324

12. Jansen GR, Zanetti ME, Hutchinson CF (1967) Studies on lipogenesis in vivo. Fatty acid and cholesterol synthesis in hyperglycemic-obese mice. Biochem J 102: 870-877

13. Christophe J, Mayer J (1959) Effects of chronic treatment with carbutamide on distribution and biosynthesis of fatty acids and cholesterol in obese-hyperglycemic mice. Am J Physiol 196: $603-606$

Received: 8 February 1983

and in revised form: 5 January 1984

Dr. Kenneth R. Feingold

Metabolism Section (111-F)

Veterans Administration Medical Center

4150 Clement Street

San Francisco, CA 94121

USA 